\title{
Climate, nitrogen and grass. 6. Comparison of yield and chemical composition of some temperate and tropical grass species grown at different temperatures
}

\author{
B. Deinum and J. G. P. Dirven
}

Department of Field Crops and Grassland Husbandry, Agricultural University, Wageningen, the Netherlands

Accepted: 13 December 1974

\section{Summary}

Two temperate grasses (Lolium perenne L. and Festuca arundinacea Schreb.) and two tropical grasses (Axonopus compressus Beauv. and Brachiaria ruziziensis Germain et Evrard) were grown in temperature-controlled greenhouses under day/ night regimes of $19 / 12,24 / 18,28 / 23$ and $34 / 30{ }^{\circ} \mathrm{C}$. Plants were grown at intermediate and high nitrogen fertilization as small swards in pots, and regrowth was harvested after 18 and 35 days.

The stemmy Brachiaria was much more productive than the other species which remained vegetative. The optimum day temperature for production was $24^{\circ} \mathrm{C}$ or lower in the temperate grasses, but over $30^{\circ} \mathrm{C}$ in the tropical species. Highest production was found after 35 days and with high nitrogen fertilization.

Lolium had the highest average content of nitrogen, soluble carbohydrates and digestibility in vitro and Brachiaria the lowest, the differences being smallest at the low temperature. There was a consistent decline in digestibility of all species with increase in temperature and age, greatest for Brachiaria. These negative effects were always caused both by an increase in content of cell-wall constituents and a decrease in their digestibility. Nitrogen fertilization had no effect on digestibility.

This trial revealed that the relationship between water consumption and crudefibre content was not causative but was established by differences in dry-matter content.

The results support the hypothesis that the low digestibility of tropical grasses is mainly due to the high temperature in which they grow, but that digestibility may be improved appreciably if stem formation is suppressed.

\section{Introduction}

Comparison of quality of various grasses from different parts of the world reveals that tropical and subtropical grasses contain much less protein and net energy than temperate grasses. This discrepancy is attributed mainly to the mineral shortage of 
tropical soils and to the maturity of the grass when harvested, the forage mainly consisting of stems. The low content of protein can be increased by sowing legumes, by nitrogen dressing and by grazing or harvesting at a younger stage. However, improvement of the net energy content does not seem simple.

Reviewing literature, Hardison (1966) concluded that total digestible nutrients and not protein content of tropical forage was the main limiting factor for higher milk production. Dirven (1965) found the same for young well-fertilized Pangola grass (Digitaria decumbens) in Surinam, as did Hamilton (1970) for Chloris gayana and Setaria sphacelata in Queensland, Australia. Moreover, Minson \& McLeod (1970) calculated from hundreds of digestion trials an average difference in digestibility of $12.8 \%$ in favour of temperate over tropical grasses.

Deinum (1966a, 1966b) found that the nutritive value of vegetative Lolium perenne decreased with temperature suggesting that the poor quality of grass in the tropics might be due to the prevailing high temperature. Climate rather than genetics could be a major factor in forage quality. Morphological development of a tropical grass species proved important too (Deinum \& Dirven, 1972).

To assess the quantitative importance of climate and genetics, yields, morphological characteristics, chemical composition and digestibility of some temperate and tropical grasses were estimated after regrowth at different constant temperatures, to different stages and with different amounts of nitrogen fertilizer. The most important results will be summarized in this paper, in which digestibility of organic matter is especially emphasized.

\section{Material and methods}

Grasses were grown in pots for 18 and 35 days at 3 temperatures in temperaturecontrolled greenhouses with 2 levels of nitrogen fertilizer. From the available collection of tropical grasses, we chose the productive Brachiaria ruziziensis Germain et Evrard and the unproductive Axonopus compressus Beauv. because they could easily be separated into different plant parts. From the temperate grasses, we chose the ubiquitous and popular Lolium perenne L. from the cooler climates and Festuca arundinacea Schreb., which is a useful grass in the slightly warmer areas.

Late in March 1966 tillers of Axonopus, Brachiaria, Festuca and Lolium were planted in 5-litre plastic pots filled with sandy soil at 28,14, 31 and 31 tillers per pot, respectively. On 27 May, after swards were established, the tillers were clipped at about $4 \mathrm{~cm}$ above ground and the pots were distributed to 4 glasshouses with temperature cycles lasting $12 \mathrm{~h}$ and $12 \mathrm{~h}$ of $19 / 12,24 / 18,28 / 23$ and $34 / 30{ }^{\circ} \mathrm{C}$ $\left(\mathrm{T}_{1}, \mathrm{~T}_{2}, \mathrm{~T}_{3}, \mathrm{~T}_{4}\right.$, respectively).

All pots were adequately dressed with the same amount of minerals except nitrogen. In treatment $N_{1}$ the nitrogen dressing was calculated to be enough to yield a nitrogen content in forage dry matter of $2 \%$; in treatment $\mathrm{N}_{2}, 4 \%$. This procedure was possible because dry-matter production could be predicted from previous results. The quantities applied are presented in Table 1.

All grasses were grown at natural day length (about $16 \mathrm{~h}$ ) and at about $80 \%$ of natural light intensity. Average daily radiation $(400-10000 \mathrm{~nm})$ inside the

Neth. J. agric. Sci. 23 (1975) 
Table 1. Nitrogen dressing ( $\mathrm{g}$ per pot) for the grasses. The smaller dressing was predicted to yield a nitrogen content of $2 \%\left(\mathrm{~N}_{1}\right)$, the larger dressing $4 \%\left(\mathrm{~N}_{2}\right)$.

\begin{tabular}{|c|c|c|c|c|}
\hline \multirow[t]{2}{*}{ Species } & \multicolumn{2}{|c|}{18 days } & \multicolumn{2}{|c|}{35 days } \\
\hline & $N_{1}$ & $N_{2}$ & $\mathrm{~N}_{l}$ & $\mathbf{N}_{2}$ \\
\hline Lolium perenne & 0.49 & 2.03 & 0.91 & 4.55 \\
\hline Festuca arundinacea & 0.49 & 2.03 & 0.91 & 4.55 \\
\hline Axonopus compressus & 0.35 & 1.33 & 0.77 & 3.01 \\
\hline Brachiaria ruziziensis & 0.70 & 2.80 & 2.10 & 7.70 \\
\hline
\end{tabular}

greenhouse was $1403 \mathrm{~J} \cdot \mathrm{cm}^{2}$ during the first period (18 days) and only 1068 $\mathrm{J} \cdot \mathrm{cm}^{-2}$ in the second period (17 days). Average relative humidity was about $80 \%$ during the day except in $\mathrm{T}_{4}$ in which it was about $60 \%$.

Pots were watered adequately and water consumption was measured. After 18 days 10 pots were harvested for each treatment and after 35 days another 6 pots. Herbage was dried at $70^{\circ} \mathrm{C}$ and separated into leaf blade and leaf sheath + stem and the number of tillers was counted. After grinding, the leaf blade and leaf sheath + stem samples were analysed for total nitrogen ( $\%$ total $\mathrm{N}$ ), nitrate nitrogen (\% $\mathrm{NO}_{3}-\mathrm{N}$ ), ash, water-soluble carbohydrates (\% wsc) and crude fibre (\% cf). Cellwall constituents $(\% \mathrm{cwc})$ and true digestibility of organic matter in vitro $\left(\mathrm{D}_{\text {vitro }}\right)$ were estimated by the procedures of Van Soest (Deinum et al., 1968). Organic nitrogen $(\%$ org. $\mathrm{N}$ ) was calculated by subtracting nitrate nitrogen from total nitrogen and digestibility in vitro of cell-wall constituents $\left(D_{e w c}\right)$ from $D_{\text {vitro }}$ and $\%$ cwc. $\left(D_{\text {vitro }}\right.$ is usually about 13 percentage units higher than apparent digestibility of organic matter in vivo).

\section{Results and discussion}

\section{Production, morphological composition and water consumption}

Dry-matter production. The average results of the four grasses are presented in

Table 2. Average yield, morphological characters and water consumption of the four grasses.

\begin{tabular}{|c|c|c|c|c|c|c|c|}
\hline Species & $\begin{array}{l}\text { Dry } \\
\text { matter } \\
\text { (g/pot) }\end{array}$ & $\begin{array}{l}\text { Dry } \\
\text { matter } \\
(\%)\end{array}$ & $\begin{array}{l}\text { Tillers } \\
\text { per } \\
\text { pot }\end{array}$ & $\begin{array}{l}\text { Dry } \\
\text { weight of } \\
\text { tillers } \\
\text { (g/100 } \\
\text { tillers) }\end{array}$ & $\begin{array}{l}\text { Leaf } \\
\text { weight } \\
\text { (\% of } \\
\text { dry } \\
\text { weight) }\end{array}$ & $\begin{array}{l}\text { Water } \\
\text { con- } \\
\text { sumption } \\
\text { (g)/dry } \\
\text { matter } \\
\text { (g) }\end{array}$ & $\begin{array}{l}\text { Water } \\
\text { con- } \\
\text { sumption } \\
\text { (g)/fresh } \\
\text { weight } \\
\text { (g) }\end{array}$ \\
\hline Lolium & 23.2 & 16.8 & 406 & 5.6 & 75.9 & 442 & 102.4 \\
\hline Festuca & 19.6 & 16.2 & 152 & 12.2 & 80.1 & 402 & 81.3 \\
\hline Axonopus & 20.5 & 18.4 & - & - & 58.5 & 296 & 96.0 \\
\hline Brachiaria & 56.3 & 15.1 & 107 & 50.2 & 54.3 & 207 & 60.9 \\
\hline
\end{tabular}




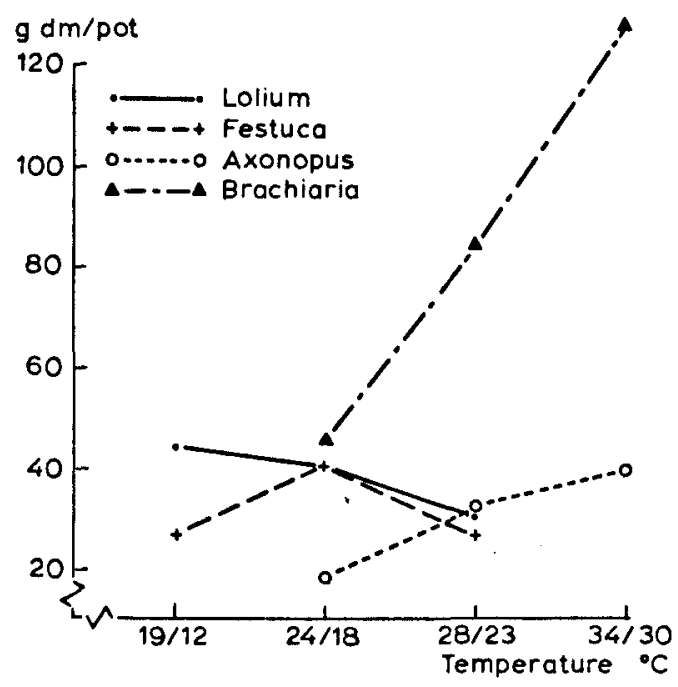

Table 2, which shows that Brachiaria was much more productive than the favoured temperate grasses. To which extent this may be attributed to the higher rate of photosynthesis per unit leaf area is not clear. Brachiaria certainly intercepted more light due to the longer stems which spread far beyond the rims of the pots in this trial. Axonopus (an excellent turf grass) proved no more productive than the two temperate grasses at the conditions of this experiment.

Lolium grew best with temperature cycles of about $19 / 12^{\circ} \mathrm{C}$, slightly decreasing in yield with higher temperatures; the optimum temperature for Festuca was about $5^{\circ} \mathrm{C}$ higher (Fig. 1, Table 3). Higher temperature greatly stimulated production of Axonopus and Brachiaria whose optimum temperatures seemed to lie beyond $34 / 30^{\circ} \mathrm{C}$. The relative effects were similar, but the absolute effect was much greater in Brachiaria than in Axonopus.

Table 3. Effect of temperature, amount of nitrogen fertilizer and age on dry-matter yield of the grasses $(\mathrm{g} / \mathrm{pot})$.

\begin{tabular}{|c|c|c|c|c|c|c|c|c|}
\hline \multirow[t]{2}{*}{ Species } & \multicolumn{4}{|c|}{ Temperature ${ }^{1}$} & \multicolumn{2}{|c|}{$\begin{array}{l}\text { Nitrogen } \\
\text { fertilization }\end{array}$} & \multicolumn{2}{|c|}{ Age } \\
\hline & $19 / 12$ & $24 / 18$ & $28 / 23$ & $34 / 30$ & $\mathrm{~N}_{1}$ & $\mathbf{N}_{2}$ & $18 \mathrm{~d}$ & s 35 days \\
\hline Lolium & 26.5 & 24.2 & 18.9 & & 17.5 & 28.9 & 17.3 & 29.2 \\
\hline Festuca & 17.4 & 23.3 & 18.1 & & 16.5 & 22.7 & 13.1 & 26.1 \\
\hline Axonopus & & 14.9 & 20.2 & 26.5 & 17.9 & 23.2 & 15.3 & 25.7 \\
\hline Brachiaria & & 29.6 & 58.5 & 80.9 & 52.5 & 60.2 & 32.5 & 80.1 \\
\hline
\end{tabular}

1 Day/night temperature in ${ }^{\circ} \mathrm{C}$. 
With more nitrogen fertilizer and longer regrowth production was higher as expected, especially at the optimum temperature.

Dry-matter content. The four grasses differed only slightly in average dry-matter content (Table 2), although the entire range was from 12.4 to $21.1 \%$ because of the different treatments.

In the temperate grasses and Axonopus dry-matter content tended to be minimum at the optimum temperature for production, as found by Grobbelaar (1963). However, the opposite is evident in Brachiaria, which may possibly be ascribed to its accelerated development at higher temperature. In a leafy stage of this grass as at low temperature, content of dry matter in leaf sheath and stem may be lower than in leaf blade, whereas in a stemmy crop as grown at high temperature, stems have a higher dry-matter' content than leaves (Dirven, unpublished data, 1967).

Age had no effect on dry-matter content, but with higher nitrogen dressings it decreased by about 2.5 percentage units on an average.

Number and weight of tillers. Morphological analyses revealed that Lolium yielded many light tillers, Festuca produced fewer heavier tillers and Brachiaria even fewer very heavy tillers. Axonopus grew as a bunch of non-reproductive stolons, defying a meaningful count of the tillers (Table 2). The average number of tillers in the pots (soil surface $0.03 \mathrm{~m}^{2}$ area) corresponded with those from favourable field circumstances.

Number of tillers was greater with more nitrogen fertilizer and with later harvesting. In Lolium number of tillers decreased with higher temperature, whereas temperature had no effect on tiller formation in Festuca. In Brachiaria, the same negative effect of temperature on tiller formation was found as in Lolium after 18 days regrowth, but after 35 days regrowth there was an inexplicable insignificant positive effect, contrary to other results with this species (Deinum \& Dirven, 1967, 1972).

Weight of tillers increased slightly with temperature in Brachiaria, but not in other grasses. It was higher after a longer growth as expected, but was not affected by amount of nitrogen fertilizer, except for a slight increase in Lolium.

Percentage leaf. Since the temperate grasses remained vegetative, 'stems' of these species consisted only of leaf sheaths and percentage leaf (leaf weight as a percentage of total weight) was much higher than in the tropical grasses (Table 2), for which much of the 'stem' fraction was true stem or stolon.

With higher temperature, temperate species were slightly more leafy but tropical grasses considerably less leafy. With longer growth most grasses were less leafy, except Axonopus, where there was no effect, perhaps because of its stoloniferous character. With the higher nitrogen dressing percentage leaf in tropical grasses was about $2.5 \%$ higher but such an effect was absent in temperate species.

\section{Water consumption}

In former trials (Deinum, 1966a, 1966b) a relationship was found between water 
consumption and \% cf in fresh grass, suggesting that environmental factors that stimulate transpiration cause proliferation of the vascular bundles. To test this hypothesis, water consumption was measured.

Water consumption divided by yield of dry matter was much less in tropical than in temperate species (Table 2), perhaps due to a higher rate of photosynthesis in tropical species (Downes, 1970). The quotient was not affected by age nor by amount of nitrogen fertilizer, except in Lolium where water was used more efficiently with more fertilizer. Grasses grown at higher temperature used more water except Brachiaria, which consumed equal quantities with $28 / 23$ and $34 / 30^{\circ} \mathrm{C}$.

However, water consumption divided by yield of fresh leaf was much more variable. Fresh leaf was expected to be an indication of transpiring area; it was calculated as though dry-matter content of leaf and stem was equal, a procedure justified within the accuracy of the data (Dirven, 1967, unpublished data). Only Brachiaria consumed water efficiently. This efficiency may be a genetic feature, but it may also be caused by a heavier shading of the lowest leaves. Consumption increased with temperature and was less with more nitrogen fertilizer.

\section{Chemical composition of bulked forage}

The average composition of the four grasses is shown in Table 4 which demonstrates the combined effects of genetic characters and different environmental conditions. Leafy temperate species had higher \% org. $\mathrm{N}$ and \% wsc, lower \% cwc and higher digestibility of organic matter $\left(D_{\text {vitro }}\right)$ and of cell-wall constituents $\left(D_{\text {cwc }}\right)$, suggesting a fair relationship with leafiness, tiller weight and chemical composition. Lolium had the largest $\%$ org. $\mathrm{N}$ and the highest $\mathrm{D}_{\text {vitro }}$. However, it is still too simple to conclude that temperate grasses are higher in quality than tropical ones.

Of the nitrogenous fractions, $\mathrm{NO}_{3}-\mathrm{N}$ content increased with nitrogen fertilization as expected; it was also significantly enhanced by age in Lolium and Axonopus, possibly because of the somewhat greater supply of $\mathrm{N}$ and the lower solar radiation during the second half of the experimental period. Temperature had a negative effect on $\% \mathrm{NO}_{3}-\mathrm{N}$, except in Lolium where it was positive, indicating that $\mathrm{NO}_{3}-\mathrm{N}$ is at minimum level at the optimum temperature for production, because of dilution over a greater quantity of dry matter of the nitrogen supplied from the soil.

Table 4. Chemical composition of the four grasses in \% of dry matter (average of all treatments) ${ }^{\mathbf{t}}$.

\begin{tabular}{lllrrrrrr}
\hline Species & $\mathrm{NO}_{3}-\mathrm{N}$ & org. $\mathrm{N}$ & ash & wsc & cwc & cf & $\mathrm{D}_{\text {cwe }}$ & $\mathrm{D}_{\text {vitro }}$ \\
& & & & & & & & \\
Lolium & 0.37 & 3.24 & 10.5 & 10.5 & 44.6 & 21.4 & 85.2 & 92.5 \\
Festuca & 0.43 & 2.98 & 9.7 & 9.2 & 48.8 & 24.3 & 81.9 & 90.1 \\
Axonopus & 0.26 & 2.83 & 8.4 & 6.1 & 58.6 & 23.6 & 79.0 & 86.2 \\
Brachiaria & 0.35 & 2.41 & 8.0 & 3.6 & 58.8 & 28.7 & 73.4 & 82.7 \\
\hline
\end{tabular}

$1 \mathrm{NO}_{3}-\mathrm{N}=$ nitrate nitrogen; org. $\mathrm{N}=$ organic nitrogen; wsc = water-soluble carbohydrates; $\mathrm{cwc}=$ cell-wall constituents; $\mathrm{cf}=$ crude fibre; $\mathrm{D}_{\text {cwe }}=$ digestibility of cell-wall constituents in vitro; $D_{\text {vitro }}=$ true digestibility of organic matter in vitro. 
Table 5. Effect of temperature, nitrogen fertilization and age on true digestibility of organic matter in vitro $\left(D_{\text {vitro }}\right)$ of the four grasses.

\begin{tabular}{|c|c|c|c|c|c|c|c|c|}
\hline \multirow[t]{2}{*}{ Species } & \multicolumn{4}{|c|}{ Temperature $^{1}$} & \multicolumn{2}{|c|}{$\begin{array}{l}\text { Nitrogen } \\
\text { fertilization }\end{array}$} & \multicolumn{2}{|l|}{ Age } \\
\hline & $19 / 12$ & $24 / 18$ & $28 / 23$ & $34 / 30$ & $N_{1}$ & $N_{2}$ & $18 \mathrm{day}$ & 35 days \\
\hline Lolium & 95.2 & 92.0 & 90.4 & & 91.9 & 93.1 & 93.4 & 91.6 \\
\hline Festuca & 94.2 & 90.1 & 86.1 & & 90.2 & 90.0 & 91.8 & 88.4 \\
\hline Axonopus & & 88.0 & 86.7 & 84.0 & 85.8 & 86.7 & 87.6 & 84.9 \\
\hline Brachiaria & & 89.4 & 80.9 & 78.0 & 82.2 & 83.2 & 86.5 & 78.9 \\
\hline
\end{tabular}

1 Day/night temperature in ${ }^{\circ} \mathrm{C}$.

The \% org. $\mathrm{N}$ was increased with nitrogen fertilizer in all four grasses, as did $\mathrm{NO}_{3}-\mathrm{N}$ content. Temperature had a similar effect on org. $\mathrm{N}$ as on $\mathrm{NO}_{3}-\mathrm{N}$. Contrary to expectation, \% org. $\mathrm{N}$ did not decrease with age, and even increased in Axonopus. This was certainly due to nitrogen application during the experiment.

Ash content reacted like that of nitrogen to environmental conditions, usually increasing with extra nitrogen, decreasing with temperature (except in Lolium) and with age (except in Axonopus).

The \% wsc was higher in the two temperate grasses and in them was greatly reduced by extra nitrogen fertilizer and by temperature, as expected. It was much lower in the old than in the young grass, certainly because of the different solar radiation during the 5 days before harvesting $\left(1567 \mathrm{~J} \cdot \mathrm{cm}^{-2} \cdot\right.$ day-1 before the first and only $777 \mathrm{~J} \cdot \mathrm{cm}^{-2} \cdot \mathrm{day}^{-1}$ before the second cutting date). In Axonopus, similar but smaller effects of age and extra nitrogen were found on \% wsc. There was no effect of temperature.

Brachiaria had very small contents and differed from the other grasses in the increase in \% wsc with temperature, as found by Wilson \& Ford (1973) for some other tropical grasses. However, in other trials they found a slight negative effect or none. Furthermore, extra nitrogen fertilizer decreased the content only in young grass, but had an insignificant positive effect in the old grass. Maybe the normal negative effect of nitrogen disappears if $\%$ wsc is very low $(1.8 \%)$.

The $\% \mathrm{cwc}$ and $\% \mathrm{cf}$ increased with temperature and age in all grasses but $\mathrm{D}_{\text {vitro }}$ and $D_{\text {ewc }}$ decreased both in leaves and stems. (The relatively high $\% \mathrm{cwc}$ to $\% \mathrm{cf}$ in Axonopus was due to the incomplete solution of protein in the neutral detergent.) This positive effect of age on $\% \mathrm{cwc}$ and $\% \mathrm{cf}$ in leaves is contrary to results for Brachiaria in 1965 and for Zea mays and Festuca arundinacea in 1964 (Deinum \& Dirven, 1972, 1971, respectively), where these contents in leaves remained constant with maturity. This again may have been caused by the extremely low solar radiation before the second cutting in the present trial. The negative effects of temperature and age on digestibility were caused both by an increase in content of cell-wall constituents and by a decrease in their digestibility.

Temperature and age affected digestibility more in Brachiaria than in the other species (Table 5), because it was more stemmy and because temperature depressed 
Table 6. Leaf percentage, chemical composition and digestibility of leaf and stem of the four grasses (average of the $24 / 18$ and $28 / 23^{\circ} \mathrm{C}$ temperature treatments) ${ }^{\mathrm{t}}$.

\begin{tabular}{|c|c|c|c|c|c|c|c|c|c|}
\hline \multirow[t]{2}{*}{ Species } & \multirow{2}{*}{$\begin{array}{l}\text { Leaf } \\
\text { weight } \\
\text { (\% of } \\
\text { dry } \\
\text { weight) }\end{array}$} & \multicolumn{2}{|c|}{$\% \mathrm{NO}_{3}-\mathrm{N}$} & \multicolumn{2}{|c|}{$\%$ org. $\mathrm{N}$} & \multicolumn{2}{|c|}{$\%$ cwc } & \multicolumn{2}{|c|}{$D_{\text {vitro }}$} \\
\hline & & leaf & $\overline{\text { stem }}$ & $\overline{\text { leaf }}$ & $\overline{\text { stem }}$ & leaf & $\overline{\text { stem }}$ & $\overline{\text { leaf }}$ & stem \\
\hline Lolium & 76.5 & 0.39 & 0.48 & 3.69 & 2.29 & 50.8 & 55.7 & 92.1 & 88.2 \\
\hline Festuca & 80.6 & 0.41 & 0.49 & 3.17 & 1.65 & 55.0 & 62.5 & 89.0 & 84.1 \\
\hline Axonopus & 60.3 & 0.23 & 0.35 & 3.42 & 2.19 & $65.5^{2}$ & 65.3 & 89.9 & 83.7 \\
\hline Brachiaria & 58.0 & 0.36 & 0.56 & 3.33 & 1.77 & 56.0 & 71.9 & 88.4 & 80.9 \\
\hline
\end{tabular}

$1 \% \mathrm{NO}_{3}-\mathrm{N}=$ nitrate-nitrogen content of dry matter; \% org. $\mathrm{N}=$ organic-nitrogen content of dry matter; $\%$ cwc $=\%$ cell-wall constituents of dry matter; $\mathrm{D}_{\text {vitro }}=$ true digestibility of organic matter in vitro.

2 Too high because of the poor solubility of protein in the neutral-detergent solution.

stem digestibility more than leaf digestibility. Extra nitrogen did not affect $\mathrm{D}_{\text {vitro }}$ although it decreased $\%$ cwc and \% cf somewhat.

\section{Composition of different grasses}

Tables 2 and 4 suggest that the poor quality of tropical grasses was partly due to their poor leafiness. Table 6 shows the content of some chemical constituents in leaves and stems, and supports this possibility. Data from the intermediate temperature treatments $\left(24 / 18,28 / 23^{\circ} \mathrm{C}\right)$ were used for this table, so that environmental conditions were the same, though temperatures were below optimum for the tropical species and beyond optimum for the temperate ones. In line with results of Minson et al. (1964), Lolium showed the highest \% org. $\mathrm{N}$ and $\mathrm{D}_{\text {vitro }}$ and is clearly an exceptional grass. Taking Festuca as more typical of the temperate grasses, Table 6 suggests that $\%$ org. $N$ and $D_{\text {vitro }}$ of leaves of some temperate and tropical grasses may be similar when grown under identical environmental conditions. However, possibly because of the different morphological developments of the plants interspecific differences are somewhat greater with regard to stem digestibility.

Simultaneously with this trial 8 tropical grasses were grown but with only 2 or 3 pots per species. They were cut at 35 days after growing with the higher nitrogen dressing at the three highest temperatures. For some, organic matter was a digestible as for Brachiaria but for others, substantially less digestible (Deinum \& Dirven, 1974).

\section{Composition of leaves and stems}

It is apparent from Table 6 and Fig. 2 that $\% \mathrm{NO}_{3}-\mathrm{N}$ and $\%$ wsc was higher and $\%$ org. $\mathrm{N}$ lower in stems than in leaves; however, \% cwc was higher in stems and $\mathrm{D}_{\text {vitro }}$ generally lower.

Fig. 2 suggests that this was true of almost all samples collected from the differ- 

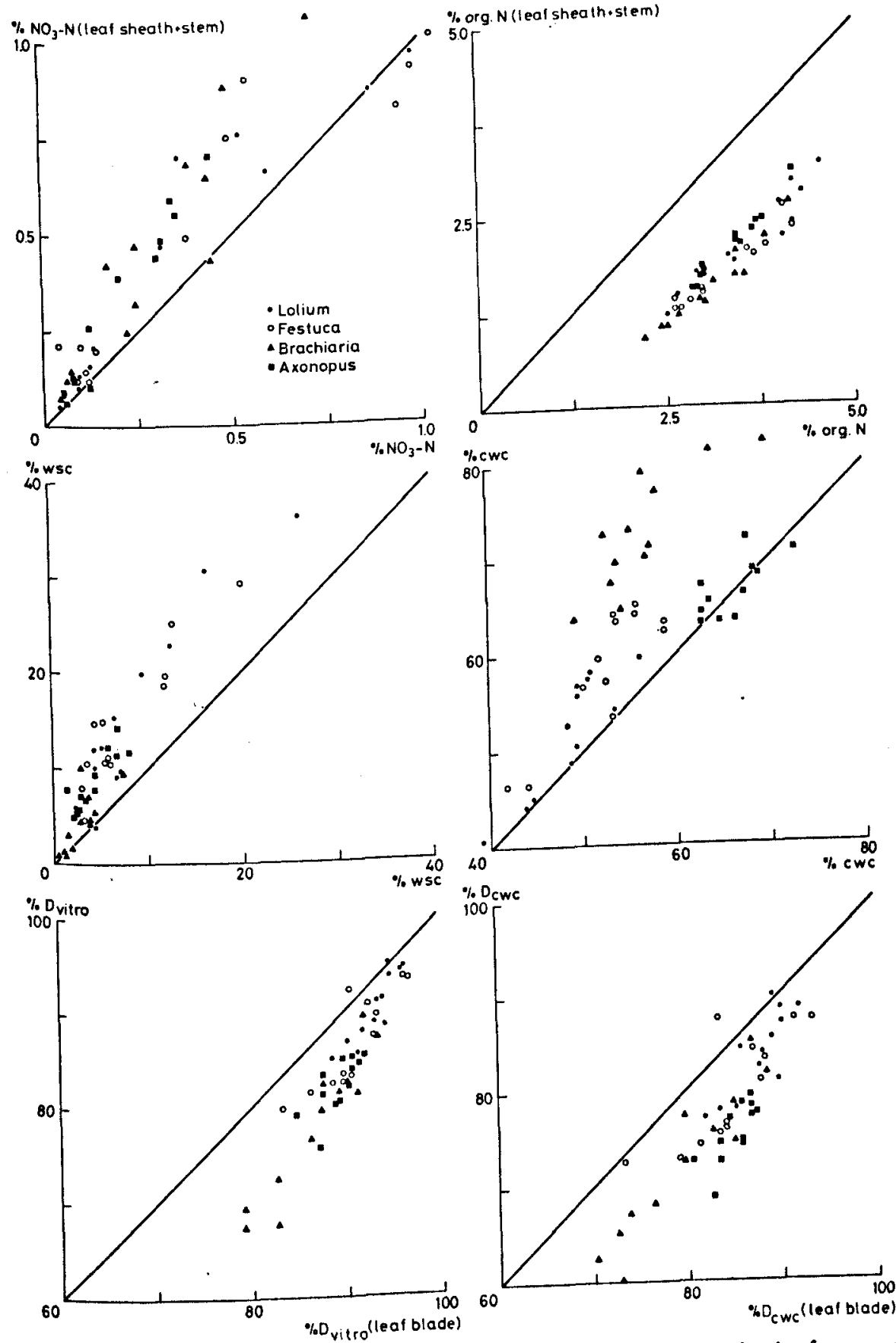

. Retationship between chemical composition of leaf and stem in the four grasses '(leaf

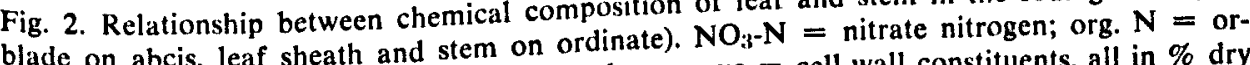
blade on abcis, leaf sheath and stem on orbohydrates; $\mathrm{cwc}=$ cell-wall constituents, all in $\%$ dry ganic nitrogen; wsc $=$ water-soluble carbohy matter in vitro; $D_{c w c}=$ digestibility of cell-wall matter; $\mathrm{D}_{\text {vitro }}=$ true digestibility of organic matter constituents in vitro.

Neth. J. agric. Sci. 23 (1975) 
ent grasses as well as for the bulked forage. Striking is the close relationship between \% org. $\mathrm{N}$ in leaves and stems, which is almost identical for all grasses.

\section{Regression of digestibility of the four grasses on temperature, age and stem for- mation}

The results of this trial provide a measure of the effect of temperature and age, and if some assumptions are made, the effect of stem formation on digestibility. However, since stem formation is crucial for digestibility, effects of temperature and age were assessed for both vegetative and elongated grass.

To calculate the digestibility of vegetative tropical grass it seemed acceptable to start from the vegetative temperate grasses, the leaf percentage of which is about $75 \%$ and whose digestibility of leaf sheath fraction is closely related to leaf blade digestibility $\left(D_{\text {sheath }}=1.45 D_{\text {hlade }}-45\right)$ (Fig. 2$)$. If the vegetative tropical grasses having the same leaf percentage and the same relationship between $D_{\text {sheath }}$ and $D_{\text {blate, }}$, one can compute the regressions on temperature and age. In addition, the effects of these factors in the elongated grass can be calculated from the data obtained.

The results of both calculations are shown in Table 7. This table reveals that the average decline in $D_{\text {vitro }}$ for the vegetative crop was about $0.5 \%$ per ${ }^{\circ} \mathrm{C}$ temperature increase, a value which agrees well with the results of Deinum et al. (1968) for digestibility in vivo of Lolium perenne. In addition, digestibility declined about $0.2 \%$ per day on an average.

In elongated Brachiaria the effects of temperature and age were much greater $\left(-1.02 \%\right.$ per ${ }^{\circ} \mathrm{C}$ and $-0.44 \%$ per day, respectively) than in the vegetative crop. The decline of $1.02 \%$ per ${ }^{\circ} \mathrm{C}$ approaches the coefficient found by Minson \& McLeod (1970) $\left(-1.14 \%\right.$ per $\left.{ }^{\circ} \mathrm{C}\right)$ for a large group of forages of unmentioned leafiness. It corresponds with the average effects found in the other eight grasses grown simultaneously (Deinum \& Dirven, 1974). However, Axonopus was exceptional showing only minor effects of temperature and age on digestibility. Furthermore, Table 7 shows the detrimental effect of stem formation, especially when cut later. The values in the last 2 columns represent the differences between

Table 7. Effect of $1^{\circ} \mathrm{C}$ temperature increase, of 1 day of age and of stem formation on digestibility of the four grasses.

\begin{tabular}{lllll}
\hline Species & Temperature & Age & & \multicolumn{2}{l}{ Stem formation } \\
\cline { 2 - 4 } & & & & \\
Lolium & & & & \\
Festuca & -0.41 & -0.11 & & \\
Axonopus & -0.76 & -0.19 & & \\
Brachiaria veg. & -0.38 & -0.16 & & \\
Brachiaria elong. & -0.79 & -0.33 & -1.7 & -3.6 \\
\hline
\end{tabular}

1 Stolons included. 


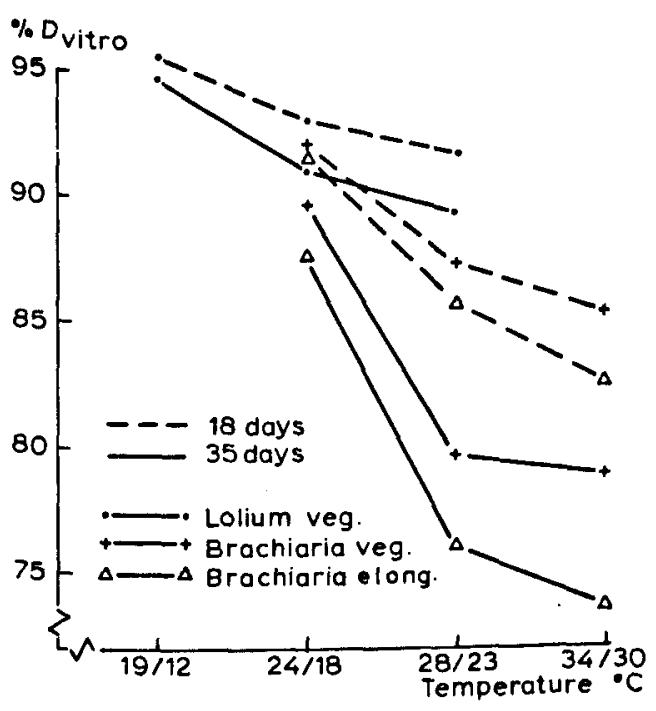

Fig. 3. Effect of temperature, age and stem formation on digestibility of organic matter in vitro of Lolium perenne and Brachiaria ruziziensis.

the average digestibilities of the elongated and the - calculated - vegetative crops. Table 7 mentions only the main effects of temperature, age and stem formation. However, significant interactions were evident (Fig. 3), for instance, the effect of temperature is more negative in old than in young grass, both in the vegetative and elongated stage indicating that a high temperature stimulates the effect of ageing. Fig. 3 also reveals that the effect of temperature and age were much greater in Brachiaria than in Lolium.

Relationship between water consumption and chemical composition As before (Deinum, 1966), a fair correlation was found between water consumption and $\%$ cf in fresh leaf of Brachiaria (Fig. 4), suggesting a causal relationship. How-

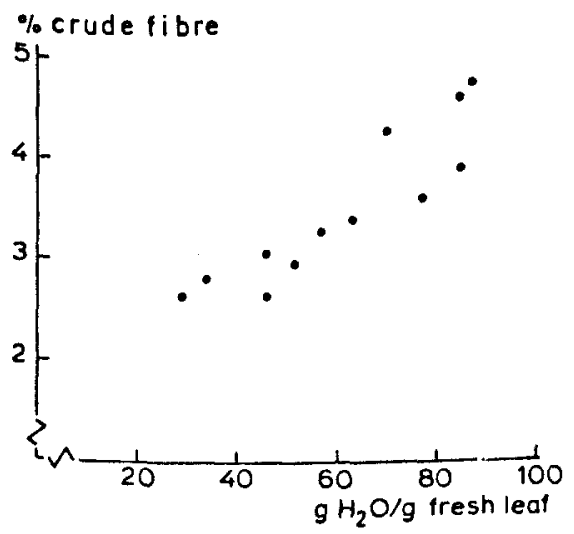

Fig. 4. Correlation between water consumption and crude-fibre content in fresh leaf of Brachiaria ruziziensis. 
ever, closer examination of the present results and of other ones (Deinum, unpublished) reveal that the correlation was spurious, being due to the great influence of the dry-matter content; environmental conditions that favour a high dry-matter content (high irradiance, nitrogen deficiency, temporary and permanent drought, low relative humidity) result in a high water consumption per unit fresh-leaf weight and a high $\%$ cf in fresh leaves. Consequently, by correcting for differences in drymatter content the relationship between chemical composition and water consumption in the grasses was almost entirely accounted for.

\section{Relationship between digestibility and crude-fibre content of organic matter}

The $\% \mathrm{cf}$ is a general reference in predicting the nutritive value of forages (digestitibility, total digestible nutrients or net energy). Although crude fibre is not an ideal reference, it works acceptably for temperate regions, but not so well for tropical grasses (Dijkstra \& Dirven, 1962; Milford \& Minson, 1960).

The data of this trial allowed us to calculate the relationship between true digestibility in vitro and crude-fibre content of organic matter in the different grasses under various environmental conditions (Table 8 ).

This table reveals that in leaves and stems of vegetative Lolium and Festuca and in the stoloniferous Axonopus the correlation is even higher than Dijkstra (1969) found in fresh grass from Dutch pastures. However, the correlation was lower in

Table 8. Relationship between true digestibility of organic matter in vitro and crude-fibre content of organic matter in leaves and stems of the four grassès $\left(y=a_{0}+a_{1} x\right)^{1}$.

\begin{tabular}{|c|c|c|c|c|c|c|c|}
\hline Treatment & $\mathrm{n}$ & $a_{0}$ & $a_{1}$ & $\mathrm{r}^{2}$ & $\begin{array}{l}\text { sd } \\
\text { (residual) }\end{array}$ & $\bar{y}$ & $\bar{x}$ \\
\hline Lolium & 24 & 112.7 & -0.87 & 0.56 & 2.24 & 91.7 & 24.0 \\
\hline Festuca & 24 & 121.8 & -1.21 & 0.78 & 2.35 & 88.8 & 27.3 \\
\hline Axonopus & 24 & 125.0 & -1.51 & 0.88 & 1.49 & 85.7 & 26.0 \\
\hline Brachiaria & 24 & 110.0 & -0.86 & 0.67 & 4.24 & 83.0 & 31.5 \\
\hline $19 / 12^{\circ} \mathrm{C}$ & 16 & 106.2 & -0.54 & 0.62 & 1.23 & 94.1 & 22.4 \\
\hline $24 / 18^{\circ} \mathrm{C}$ & 32 & 107.2 & -0.68 & 0.52 & 2.53 & 89.0 & 26.7 \\
\hline $28 / 23^{\circ} \mathrm{C}$ & 32 & 107.0 & -0.75 & 0.58 & 3.20 & 85.4 & 28.7 \\
\hline $34 / 30^{\circ} \mathrm{C}$ & 16 & 111.4 & -1.02 & 0.87 & 2.45 & 81.0 & 29.9 \\
\hline Leaves & 48 & 117.0 & -1.08 & 0.49 & 2.92 & 90.0 & 24.9 \\
\hline Stems & 48 & 111.6 & -0.91 & 0.69 & 3.67 & 84.6 & 29.5 \\
\hline Leaves + stems & 96 & 114.2 & -0.98 & 0.70 & 3.33 & 87.3 & 27.2 \\
\hline Whole crops ${ }^{2}$ & 48 & 120.4 & -1.21 & 0.77 & 2.70 & 87.9 & 26.9 \\
\hline
\end{tabular}

$\mathrm{I}_{\mathrm{n}}=$ number of samples; $\mathrm{r}=$ correlation coefficient; $\mathrm{sd}$ (residual) $=$ standard deviation that cannot be explained by the regression; $\bar{x}=$ average of $x ; \bar{y}=$ average of $y$.

2 Composition of whole crop calculated from \% leaf and chemical composition of leaves and stems. 
the stemmy Brachiaria (viz standard deviation). Although it was lower than Dijkstra (1969) found in temperate grasses it was higher than he found in tropical herbage (Dijkstra \& Dirven, 1962). This poor correlation in Brachiaria was caused by the somewhat higher digestibility of stems than of leaves containing as much crude fibre.

In addition, it appeared that the regression coefficient increased with temperature, indicating that at a lower digestibility the effect of crude fibre was greater. Although a curvilinear regression would better reflect the pooled data as found by Dijkstra (1966), the improvement over the linear relationship was not significant.

Consequently, for the limited range of our trial with four grasses grown under glass crude fibre is a fair reference of nutritive value in both temperate and tropical grasses.

\section{Conclusions}

In conclusion it can be stated that the poor quality of tropical forages is mainly due to the high temperature where they grow and to the large negative effects of age and stem formation. If the tendency of most tropical grasses to form stems be suppressed by selection for leafiness, their quality may improve appreciably (Dirven, 1970). Even so, it will be hard to breed tropical varieties that can match the digestibility of the most popular grass species of temperate regions.

\section{Acknowledgments}

The authors are very greatful to $\mathrm{Mr}$ Koop Wind for his special care in assisting with the experiment and for the elaborate morphological separation works and the calculations.

Mrs Tyne van der Ven and Mrs Evelyn Zantman are greatly acknowledged for the chemical analyses of the samples.

\section{References}

Deinum, B., 1966a. Climate, nitrogen and grass. 1. Research into the influence of light intensity, temperature, nitrogen and water supply on the production and chemical composition of grass. Meded. LandbHogesch. Wageningen 66-11, pp. 91.

Deinum, B., 1966b. Influence of some climatological factors on the chemical composition and feeding value of herbage. Proc. 10th int. Grassland Congr. (Helsinki) 415-418.

Deinum, B. \& J. G. P. Dirven, 1967. Een oriënterende proef omtrent de invloed van licht en temperatuur op opbrengst en chemische samenstelling van Brachiaria ruziziensis Germain et Everard. Surin.Landb. 15, 5-10.

Deinum, B. \& J. G. P. Dirven, 1971. Climate, nitrogen and grass. 4. The influence of age on chemical composition and in vitro digestibility of maize (Zea mays L.) and tall fescue

(Festuca arundinacea Schreb.). Neth. J. agric. Sci. 19: 264-272.

Deinum, B. \& J. G. P. Dirven, 1972. Climate, nitrogen and grass. 5. Influence of age, light intensity and temperature on the production and chemical composition of Congo grass (Brachiaria ruziziensis Germain et Everard). Neth. J. agric. Sci. 20: 125-132.

Deinum, B. \& J. G. P. Dirven, 1973. Preliminary investigations on the digestibility of some tropical grasses grown under different temperature regimes. Surin. Landb. 21: 121-126.

Neth. J. agric. Sci. 23 (1975) 
Deinum, B., A. J. H. van Es \& P. J. Van Soest, 1968. Climate, nitrogen and grass. 2. The influence of light intensity, temperature and nitrogen on vivo digestibility of grass and the prediction of these effects from some chemical procedures. Neth. J. agric. Sci. 16: 211-216.

Dirven, J. G. P., 1965. Milk production on grassland in Surinam. Proc. 9th int. Grassland Congr. (Sao Paulo) 995-999.

Dirven, J. G. P., 1970. Die Aufgabe der Gräserzüchtung in den Tropen unter besonderer Berücksichtigung von Vermehrung, Ertrag und Futterwert. Z. KultTech. u. Flurbereinigung 11: 92-107.

Downes, R. W., 1970. Differences between tropical and temperate grasses in rates of photosynthesis and transpiration. Proc. 11th int. Grassland Congr. (Surfers Paradise) 527-530.

Dijkstra, N. D., 1966. Estimation of the nutritive value of fresh roughage. Proc. 10th int. Grassland Congr. (Helsinki) 393-397.

Dijkstra, N. D., 1969. Evaluation of the nutritive value of grassland products by means of in vivo and in vitro digestibility. Proc. 3rd gen. Meet. Eur. Grassland Fed. (Braunschweig) 267-273.

Dijkstra, N. D. \& J. G. P. Dirven, 1962. Digestibility and feeding value of some tropical grasses and kudzu. Neth. J. agric. Sci. 10: 275-285.

Grobbelaar, W. P., 1963. Responses of young maize plants to root temperatures. Meded. LandbHogesch. Wageningen 63-5, pp. 71.

Hamilton, R. I., L. J. Lambourne, R. Roe \& D. J. Minson, 1971. Quality of tropical grasses for milk production. Proc. 1lth int. Grassland Congr. (Surfers Paradise) 860-864.

Hardison, W. A., 1966. Chemical composition, nutrient content and potential milk production capacity of fresh tropical herbage. Tech. Bull. Dairy Training Res. Inst. Philippines 1, pp. 54.

Milford, R., 1960. Criteria for expressing nutritional values of subtropical grasses. Aust. J. agric. Res. 11: 121-137.

Minson, D. J. \& M. N. McLeod, 1970. The digestibility of temperate and tropical grasses. Proc. 11 th int. Grassland Congr. (Surfers Paradise) 719-732.

Minson, D. J., C. E. Harris, W. F. Raymond \& R. Milford, 1964. The digestibility and voluntary intake of S22 and H1 ryegrass, S170 tall fescue, S48 timothy, S215 meadow fescue and Germinal cocksfoot. J. Br. Grassland Soc. 19: 290-305.

Wilson, J. R. \& C. W. Ford, 1971. Temperature influences on the growth, digestibility and carbohydrate composition of two tropical grasses, Panicum maximum var. trichoglume and Setaria sphacelata, and two cultivars of the temperate grass Lolium perenne. Aust. J. agric. Res. 22: 563-571.

Wilson, J. R. \& C. W. Ford, 1973. Temperature influences on the in vitro digestibility and soluble carbohydrate accumulation of tropical and temperate grasses. Aust. J. agric. Res. 24: 187-198. 